\title{
One-Gate Public Service for Developing Local Wisdom-based Tourism in Banyumas, Central Java: An Alternative Solution?
}

\author{
Triana Ahdiati ${ }^{1}$, Oktafiani Catur Pratiwi ${ }^{2}$ \\ ${ }^{1}$ Political Science Department, Jenderal Soedirman University (triana.ahdiati@unsoed.ac.id) \\ ${ }^{2}$ Political Science Department, Jenderal Soedirman University (oktafiani.cp@gmail.com)
}

\begin{abstract}
This paper aims at analyzing the development of tourism at the local level. Recently, tourism in Indonesia becomes the mainstay for increasing regional income as well as functioning as the tool of environmental conservation, both the natural and social environment. However, local tourism in Indonesia has not been developed to its full potential because the government heavily does the promotion only without considering the sustainability of the environment itself. In this case, tourism is merely used as a commodity or marketable goods simply to raise regional income by ignoring the environmental sustainability that leads to environmental damage. Institutionally, this can be seen from the presence of the Indonesian Tourism Promotion Board or Badan Promosi Pariwisata Indonesia (BPPI) that are focused on promoting national and local tourism. As a matter of fact, the development of tourism needs an intergovernmental management from the related ministries. Unfortunately, each ministry is not integrated in a single institution functioned to coordinate all ministries involved in tourism development. Therefore, it is very important to set up an institution in charge of developing tourism from the national level to the local level by utilizing local wisdom respectively, including the development of tourism in Banyumas, Central Java.
\end{abstract}

Keywords: One-gate system, institutionalization, local tourism

\section{Introduction}

Creative tourism, which offers various creative experiences such as arts, crafts and culinary activities to the visitors, becomes a new weapon for tourism marketing in Indonesia, both national and local tourism. Such experiences enable the visitors to stay longer in Indonesia with high quality accommodation and connected to the local.

The Bali bombing tragedy has pointed out that the tourism development in Indonesia cannot rely on one region. Instead, this tragedy has already given a very expensive lesson to Indonesia as follows: first, the tourism development approach orienting toward foreign markets cannot support the goals of developing tourism in Indonesia. Second, the tourism development focused only on one main gate has many weaknesses. Third, the people's activities in one tourism destination need to be diversified to make an alternative income for both central and local government.
One of the efforts to awaken and develop local tourism is by establishing the Indonesian Tourism Promotion Board or Badan Promosi Pariwisata Indonesia (BPPI) which becomes the working partner of the Tourism and Creative Economy Ministry established by the Presidential Decree Number 22/2011 on the Indonesian Tourism Promotion Board. The main task of BPPI is as follows: 1) improving the tourism image in Indonesia; 2) increasing the number of visitors from all over the world as well as the foreign exchange earnings; 3) increasing the number of domestic tourists as well as the expenditure; 4) doing the research on developing the tourism business. In this case, BPPI functions as the coordinator of the tourism promotion activities carried out by the commercial enterprises in both central and local level. In addition, BPPI also becomes the working partner of both the central and local government.

At the local level, tourism development is organized by Dinbudpar (Dinas Kebudayaan dan Pariwisatal 
the Office of Culture and Tourism or Dinporabudpar

(Dinas Pemuda Olahraga Kebudayaan dan Pariwisatal the Office of Youth Sport Culture and Tourism). In this case, the name of the office depends on the local policy of STOK (Satuan Organisasi dan Tata Kerja/ The Unit of Organization and the Work Procedures) referring to Permendagri Nomor 39 Tahun 2012/ The Regulation of Home Affairs Minister on the Organization of Local Apparatus. As a matter of fact, it seems that there is no interregional as well as intergovernmental coordination for developing tourism itself. In this case, local autonomy is understood differently among the stakeholders. Moreover, it is taken exaggeratedly in the effort of increasing the regional income. Instead of rousing local initiatives, each region does show the competition in developing tourism merely to increase the regional income as much as possible through increasing tax and retribution. As the consequence, the interregional egocentrism turns up in the development itself. This can be seen from the tourism development in Indonesia, including Banyumas as one of the potential tourism areas in Central Java.

\section{Research Methodology}

This paper is written based on the result of the research about tourism and its development in Banyumas, Central Java (Ahdiati \& Kusumanegara 2008; Soebiantoro et. al. 2010; Ahdiati \& Kusumanegara 2012). The research used a qualitative method with an action research (Islamy 2003, p. 89) as its approach. There are three types of data sources collected in the research, i.e.: 1) the informants covering local government, community leaders -both from the cultural actors and the entrepreneurs as well- and the local community, commercial enterprises and visitors. The data was collected by doing in-depth interviews and focus group discussion $(F G D) ; 2)$ the research location covering the sites and the events associated with the tourism development in Banyumas, Central Java. This kind of data was collected by having observation towards the research location; 3) the documents related to the focus of the research. This kind of data was collected by doing documentation study. The data collected in the research is analyzed by using a model of interactive analysis from Miles and Huberman (Miles \& Huberman 1992, p. 20). To get a good conclusion, the result of the research is validated by a technique of triangulation (Lincoln \& Guba 2009, p. 195).

\section{Tourism And Its Institutions in The Era of Local Autonomy}

As a part of national development, the tourism development in every region of Indonesia has to be integrated holistically. This is because tourism itself is defined as "the processes, activities, and outcomes arising from the relationships and the interactions among tourists, tourism suppliers, host governments, host communities, and surrounding environments that are involved in the attracting and hosting of visitors." (Goeldner \& Ritchie 2009, p. 6) In the era of local autonomy, tourism -which is defined as the decentralization of authority from the central government to the local ones to organize their own internal affairs(Undang-Undang Nomor 32 Tahun 2004 tentang Pemerintahan Daerah/ the Act of $32 / 2004$ on Local Government)- brings the consequence of decentralizing authority or delegating the governmental affairs from the central government to the local ones in organizing tourism development. That is why it is needed an organization as well as the 
network system of the relevant actors to reach the goals through developing tourism itself.

Institutionally, tourism in Banyumas is organized under Dinporabudpar. It means that an office does not only organize the sector of tourism, but also organizes the sectors of youth, sport and culture. In addition, tourism is also seen as an industry organized by both government and commercial enterprises. That is why business sector in tourism becomes the important thing on account of providing tourism facilities such as hotels, restaurants, souvenir shops, tour and travel bureaus, tourism education and other supporting facilities (Spillane 1994, p. 40).

\section{The Policy Of Tourism Development In Banyumas, Central Java}

Banyumas is one of the regions in Indonesia which is active in the implementation of local autonomy. In the leadership of Mardjoko as the Banyumas regent for the period of 2008 - 2013, the jargon of investment becomes a method or strategy to make investors come and invest their capital in the region. Some of the investors in Banyumas are able to support the tourism business in the region through building the famous four-star hotels to attract both domestic and foreign tourists. There are five tourism components, i.e. natural sources, infrastructure, transportation, hospitality and cultural resources. In this case, business sector has an important role in providing infrastructure and transportation. In Banyumas, for example, the growth of transportation business can be seen from the presence of tour and travel bureaus that provide the service of transportation to connect Banyumas with Yogyakarta, Surakarta, Semarang, Magelang, Tegal and other regions. For natural resources, the leading tourist attractions in Banyumas are Baturaden and Curug
Cipendok. Meanwhile, hospitality and cultural resources are provided by the local people living around the tourism places. In this case, hospitality and culture owned by the people are able to be the main attractions for the visitors on account of being specific and unique. The specific characteristic of Banyumas people which becomes their local identity is Cablaka, i.e. what it is, what it should be; identical or consistent with what is so-called transparency (Rozani 2010).

Nowadays, Banyumas is appointed as 'City of Holiday' planned to attract tourists. In this case, the appointment is done during the leadership of the Banyumas regent, Achmad Husein. Since 2013, several programs have been done to support the tourism development in Banyumas as follows: 1) the program of developing cultural values through the activities of preserving and actualizing the local custom; 2) the program of developing tourism marketing through the activities of managing the national tourism promotion, both at home and abroad; 3) the program of managing the cultural richness through the activities of managing and developing the preservation of ancient historical heritage, museums, underwater heritage and the festival of Banyumas culture as well; 4) the program of developing tourism destination through the activities of improving the development of tourism infrastructure, joint security and the cleanliness of tourism objects ("Rincian APBD menurut Urusan Pemerintahan Daerah, Organisasi, Pendapatan. Belanja dan Pembiayaan Tahun Anggaran 2014 (the Detail of Local Budget according to the Unit of Local Government, Organization, Revenue Expenditure and Financing for in the Fiscal Year of 2014). Those programs are quite visible to support the development of tourism in Banyumas. This can be seen from the local budget 
for the fiscal year of 2014. For example, first, the budget for the program of developing cultural values through the activities of preserving and actualizing the local custom is Rp. 100.000.000,-. Second, the budget for the program of developing tourism marketing through the activities of managing the national tourism promotion both at home and abroad is Rp. 750.000.000,-- Third, the budget for the program of managing the cultural richness through the activities of managing and developing the preservation of ancient historical heritage, museums, underwater heritage is Rp. 100.000.000,- and for the festival of Banyumas culture is Rp. 425.000.000,-Fourth, the budget for the program of developing tourism destination through the activities of improving the development of tourism infrastructure is Rp. 800.000.000,- and for joint security and the cleanliness of tourism objects is Rp. 300.000.000,("Rincian APBD menurut Urusan Pemerintahan Daerah, Organisasi, Pendapatan. Belanja dan Pembiayaan Tahun Anggaran 2014 (the Detail of Local Budget according to the Unit of Local Government, Organization, Revenue Expenditure and Financing for in the Fiscal Year of 2014). So, it is obvious that the budget is spent more on the activities of employee expenditure as well as the expenditure of goods and services.

Since tourism becomes the complex sector, then its development needs an intergovernmental management from the related ministries. Unfortunately, each ministry is not integrated in a single institution functioned to coordinate all ministries involved in tourism development. For example, what has been done by the Ministry of Tourism and Creative Economy is not in line with the Ministry of Home Affairs in developing cultural tourism. In this case, the Ministry of Home Affairs has released Permendagri No 52 Tahun 2007 (the Decree of Home Affairs Minister Number 52/2007) on the Guidance of Preserving and Developing Customs and the Social Cultural Values of the Society. The decree has assigned 47 villages in Indonesia to be desa adat (traditional village) which spread in seven regencies, i.e. Halmahera Barat (West Halmahera) in Maluku Utara (North Maluku), Maros in Sulawesi Selatan (South Sulawesi), Lima Puluh Koto in Sumatera Barat (West Sumatera), Empat Lawang in Sumatera Selatan (South Sumatera), Lebak in Banten, Tanah Laut in Kalimantan Selatan (South Kalimantan) and dan Banyumas in Jawa Tengah (Central Java). In Banyumas, particularly, there are five villages which have been assigned as the Pilot Project of Preserving the National Customs and Culture by the Ministry of Home Affairs. Those villages are Kalisalak village, Pasir Wetan village, Pekuncen village, Cikakak village and Gerduren village ("Lima Wilayah Banyumas Menjadi Desa Adat/ Five Regions in Banyumas Become Traditional Villages" 2011). The actor in charge in this program is Bapermas $P K B$ (Badan Pemberdayaan Masyarakat Penyuluh Keluarga Berencanal the Board of the Community Empowerment for Family Planning Counselors).

\section{One-Gate Public Service: An Offer For} Alternative Solution?

From several policies implemented in Banyumas, Central Java, there are several problems appeared in the developing tourism. First, tourism is still developed partially. It means that the local government develops tourism in the region without seeing, connecting with, and even integrating with the local development of the other regions nearby. Moreover, each of the regions tends to increase the 
interregional competition which brings the bad impact to the product quality; in fact, tourism has to be developed cross-regionally though. Furthermore, it has to be borderless on account of having the advancement of information technology. In this case, the local government of Banyumas has to be more synergized with other regencies nearby to develop tourism through the network of Barlingmascakeb, i.e. Banjarnegara, Purbalingga, Banyumas, Cilacap, Kebumen, so that the existence of Barlingmascakeb itself is not merely as an institution.

Second, tourism is still developed cross-cuttingly. In this case, the development of tourism in Indonesia is organized by several ministries through the relevant offices such as Dinporabudpar under the Ministry of Education and Culture, Bapermas $P K B$ under the Ministry of Home Affairs, and BPPI. This reveals increasingly the weakness of the tourism development policy, both at national and local level. Third, the development of tourism in Banyumas is still focused on the main tourism destinations, especially the natural tourism object of Baturaden. As a matter of fact, there are still other areas which are very potential to be developed as tourism objects. This can be seen from the activities of tourism infrastructure development which is centralized in one area, thus other areas are not properly developed.

Fourth, the characteristics of Banyumas region make every area different from one to another. The differences reflect in the aspects of natural tourism potentials, economy and livelihood, custom and tradition, demography, and others. It means that a pattern of tourism development is needed due to the differences. The process of deciding the pattern has to involve the active participation of all relevant actors in order to be holistic, integrative, comprehensive, and synergized as well.
The problems in developing tourism in Indonesia, especially in Banyumas, are in fact able to be overcome with an alternative solution. In this case, the government -both central and local governmenthas a pattern of one-gate system, i.e. a pattern of public service which is given in a single manner by a governmental institution based on delegating authority from other relevant institutions (Keputusan Menteri Pendayagunaan Aparatur Negara Nomor 81 Tahun 1993 tentang Pedoman Tata Laksana Pelayanan Umum (the Decree of State Apparatus Utilization Minister Number 81/1993 on the Guidance of Administrating Public Service). By involving the stakeholders from commercial enterprises and local people, in this case, all relevant ministries - such as the Ministry of Education and Culture, the Ministry of Tourism and Creative Economy, the Ministry of Home Affairs and other relevant ministries- establish an institution as a gate of public service authorized in developing tourism in Indonesia both at national and local levels. This onegate public service aims particularly at simplifying the process of the policy formulation, coordination as well as the implementation of developing tourism in Indonesia, especially in Banyumas.

\section{Conclusion}

Tourism is a sector which is so potential to be developed in Indonesia, especially in Banyumas, that needs to be packaged in the form of more interesting tourism product diversification to attract both domestic and foreign tourists. It means that developing tourism does not only involve government as an actor, but also relevant stakeholders from the commercial enterprises as well as the local people. So, the development of tourism can never succeed if each relevant ministry or office 
has a policy which is not synergized one to another. That is why one-gate public service becomes an alternative solution for developing tourism in Indonesia both at national and local levels. Thus, the development of tourism in Indonesia, especially in Banyumas, will hopefully be organized comprehensively, holistically, and integrated with other regions nearby.

\section{References}

[1] Ahdiati, T. \& Kusumanegara, S. (2008). Perspektif Ekofeminisme dalam Pengembangan Ekoturisme di Kawasan Wisata Baturaden Kabupaten Banyumas (The Ecofeminism Perspective in Developing Ecotourism in the Tourism Area of Baturaden, Banyumas). Research report, University of Jenderal Soedirman.

[2] (2012). Tourism

Politics and Local Wisdom: Revitalizing the Art of Jemblung in the Cultural Tourism Development of Banyumas, Proceeding of Indigenous Communities and "The Projects of Modernity", Yogyakarta: Gadjah Mada University,

[3] Goeldner, C. R. \& Ritchie, J. R. B. (2009). Tourism: Principles, Practice, Philoshophies, $11^{\text {th }}$ Edition. New Jersey: John Wiley \& Sons, Inc.

[4] Islamy, I. (2003). Rancangan Penelitian Tindakan/ An Action Research Design. In Masykuri Bakri (ed.), Metode Penelitian Kualitatif: Tinjauan Teoritis dan Praktis/ A Qualitative Research Method: A Theoretical and Practical Review). Malang: Unisma-Visipress

[5] 2011. Lima Wilayah Banyumas Menjadi Desa Adat/ Five Regions in Banyumas Become
Traditional Villages. Jurnal Nasional (National Journal), 5 November

[6] Lincoln, Y. \& Guba, E. G. (1984). Naturalistic Inquiry. London: Sage Publications

[7] Miles, M. B. \& Huberman, A. M. (1992). Analisis Data Kualitatif: Buku Sumber Tentang Metode-Metode Barul Qualitative Data Analysis: The Reference Book of New Methods. Jakarta: UI-Press

[8] Moleong, L. J. (2009). Metodologi Penelitian Kualitatif (Methodology of Qualitative Research). Bandung: PT. Remaja Rosdakarya

[9] Peraturan Menteri Kebudayaan dan Pariwisata Nomor PM.17/PR.001/MKP/2010, Tentang Rencana Strategis Kementerian Kebudayaan dan Pariwisata Tahun 2010-2014/ The Regulation of Culture and Tourism Minister Number PM.17/PR.001/MKP/2010 on The 2010-2014 Strategic Plan of the Culture and Tourism Ministry

[10] Permendagri Nomor 39 Tahun 2012/ the Regulation of Home Affairs Minister on the Organization of Local Apparatus.

[11] Rincian APBD menurut Urusan Pemerintahan Daerah, Organisasi, Pendapatan. Belanja dan Pembiayaan Tahun Anggaran 2014/ the Detail of Local Budget according to the Unit of Local Government, Organization, Revenue Expenditure and Financing for in the Fiscal Year of 2014," published on Monday, 3 March 2014, 13:53:15, http://www.banyumaskab.go.id/

[12] Rozani, E. (2010).Kearifan Lokal yang Semakin Terpinggirkan(The More Marginalized Local Wisdom). Freelists.org (blog), 5 June 2010 $(11.13$ a.m.). http://www.freelists.org/post/ppi/ppiindiaKearifan-Lokal-Yang-Semakin-Terpinggirkan) 
[13] Soebiantoro, M., Ahdiati, T. \& Kusumanegara, S. (2010).Pengembangan Kebijakan Pariwisata Budaya Berbasis Kearifan Lokal di Kabupaten Banyumas the Policy of Local Wisdom-Based Cultural Tourism in Banyumas). Research report, University of Jenderal Soedirman, 2010.
[14] Spillane, J. J. (1994).Pariwisata Indonesia Siasat Ekonomi Dan Rekayasa Kebudayaan/ The Indonesian Tourism and the Cultural Engineering, Yogyakarta: Kanisius, 